\title{
足趾把持測定における足趾把持バーの握り位置の検討
}

\section{Examination of toe grip bar position for measuring toe grip strength}

\author{
相馬 正之 ${ }^{11}$, 村田 伸 ${ }^{2}$, 甲斐 義浩 ${ }^{2}$

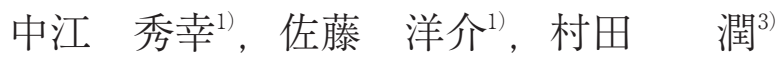 \\ Masayuki Soma $^{1)}$, Shin Murata ${ }^{2)}$, Yoshihiro Kai ${ }^{2}$
Hideyuki Nakae $^{1)}$, Yousuke Satou
}

要旨：[目的］本研究では, 足趾把持力の測定場面において適切な足趾把持バーの握り位 置を明らかにするため, 最大筋力の発揮できる位置および再現性の観点から検討した。[対 象・方法］健常成人男性 24 名を対象とした。足趾把持力の測定は，足趾把持バーを第 1 趾 節間関節（interphalangeal joint 以下，IP）直上，第 1 趾節関節より前方（IP 前方）㧍よ び後方（IP 後方）の 3 条件とした。[結果］分析の結果，IP 直上の足趾把持力は，IP 前 方㧍よび IP 後方より有意に高值を示した。また，級内相関係数（1, 1) は， 3 条件とも良 好であった。[結語] 本研究結果から, 最大筋力発揮および再現性の観点から足趾把持バー の位置は，IP 直上が適切であることが示された。

キーワード : 足趾把持力, 測定肢位, 足趾把持バーの握り位置

\begin{abstract}
Purpose] The purpose of the present study was to investigate the position of the toe grip bar at which maximum strength could be exerted during toe grip strength and measurement reproducibility. [Subjects] Twenty-four healthy young men were selected. [Methods] We measured toe grip strength during the following three positional conditions of the toe grip bar: immediately above the first interphalangeal (IP) joint, front of the IP joint, and back of the IP joint. [Results] We found that toe-grip strength was significantly higher immediately above the IP joint than at the front and back of the IP joint. Moreover, the intraclass correlation coefficient was good for the three conditions. [Conclusion] The results suggest that immediately above the IP position is the most suitable toe grip bar position for measuring toe grip strength, as this position allows maximum strength exertion and repeated measurements.
\end{abstract}

Key words: toe-grip strength, Measurement position, position of the toe grip

\footnotetext{
受付日：2020年11月 9 日, 採択日：2020年12月 7 日

1) 東北福祉大学健康科学部：干981-8522 宮城県仙台市青葉区国見 1-8-1

Faculty of Health Sciences, Tohoku Fukushi University

Tel : 022-233-3111 FAX : 022-233-3113

:1-8-1, Kunimi, Aoba-ku, Sendai-city, 981-8522, Japan

Tel:022-233-3111 FAX:022-233-3113 E-mail: souma@tfu-mail.tfu.ac.jp

2) 京都橘大学健康科学部

Faculty of Health Science, Kyoto Tachibana University

3) 長崎大学大学院 医歯薬学総合研究科保健学専攻

Department of Health Sciences, Graduate School of Biomedical Sciences, Nagasaki University
} 


\section{はじめに}

理学療法において筋力評価は, 対象者の機能評価と して必須項目である。とくに, 定量化できる Hand held dynamometer ${ }^{1,2)}$, 等速性筋力測定装置 ${ }^{3,4)}$, 握力計 ${ }^{5,6)}$ といった機器で測定される筋力は, 臨床や研究の場で 広く使用されている。なかでも握力は，上肢筋力のみ ならず全身の体力指標としても使用される ことから， 測定姿勢や肢位など詳細な測定方法の検討 ${ }^{5-8}$ が行われ てきた。例えば，座位や背臥位よりも立位で測定した 方 $^{5}$ が, 肘関節は屈曲位より伸展位の方 ${ }^{6}$ が最大握力を 発揮できることが示されている。さらに大塚ら ${ }^{8}$ は, 握力計の握り幅について遠位手掌㱀璧から示指の近位 指節間関節までの距離に $0.5 \mathrm{~cm}$ を加えた長さ, $5 \mathrm{~cm}$, 自由な長さの 3 条件で測定し，条件間に有意な差を認 めないことを示し，握り幅は握力に影響を及ぼさない ことを報告している。

上肢の握力に相当する下肢の足趾把持力は, 短母指 屈筋, 長母指屈筋, 虫様筋, 短指屈筋, 長指屈筋の作 用により起こる複合運動である ${ }^{2)}$ 。足趾把持力の測定 肢位について相馬ら ${ }^{9}$ は，足関節において背屈位およ び中間位が底屈位よりも最大発揮しやすいことを報告 している。また, 膝関節伸展位では膝関節 90 度屈曲位 よりも最大発揮しにくい(10) ことや股・膝関節 90 度屈曲 位の座位姿勢が立位姿勢と同等の足趾把持力を発揮で

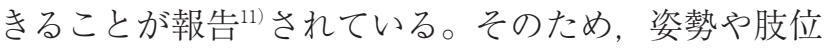
は現行法が適していることが示唆されるが, 最適な足 趾把持バーの握り位置については検討されていない。 先行研究において握り位置は, 第 1 趾節間関節 (interphalangeal joint 以下，IP） 直上 ${ }^{12.13)}$ や把持しやすい位 置 ${ }^{14,15)}$ と統一されていないのが現状である。そのため, 足趾把持バーの握り位置に焦点を当てた検証が必要と 思われる。

そこで本研究では，足趾時把持バーを IP 直上，IP より前方および後方で測定した足趾把持力を比較し, 最大筋力の発揮および測定值の再現性という観点から 足趾把持バーの握り位置について検討した。

\section{対象・方法}

\section{1 . 対 象}

対象は，健常成人男性 24 名とした。いずれも下肢に 整形外科的疾患や疼痛などの既往はなかった。対象者 の年齢は平均 $21.0 \pm 0.9$ 歳, 身長は平均 $172.4 \pm 5.0 \mathrm{~cm}$, 体重は平均 $64.8 \pm 7.2 \mathrm{~kg}$ であった。対象者には研究の 趣旨と内容, 得られたデー夕は研究の目的以外には使
用しないこと，および個人情報の漏洩に注意すること について説明し，理解を得たうえで協力を求めた。ま た，研究への参加は自由意志であり，被験者にならな くても不利益にならないことを口答と書面で説明し， 同意を得て研究を開始した。なお，本研究は，所属機 関の究倫理委員会の承認（RS150402）を受けて実施 した。

\section{2. 方 法}

測定項目は，利き足の足趾把持力とした。本研究に おける利き足の定義を，ボールを蹴る足とし，対象者 のすべてが右足であった。

足趾把持力の測定肢位は，端座位，体幹垂直位，股 および膝関節を90度屈曲，足関節底背屈中間位とし， 足関節固定ベルトを使用した。足趾把持バーの位置は, 第 1 趾節間関節（IP 直上），第 1 趾節関節より $8 \mathrm{~mm}$ 前方（IP 前方）および $8 \mathrm{~mm}$ 後方（IP 後方）の 3 条 件とした（図 1 )。この 3 条件とした理由は, 予備実 験から足趾把持バーの握りやすい位置が IP 直上もし くは IP 前方が大半を占めたため, 比較対象として IP 後方を加え，さらに足趾時把持バーの径が $8 \mathrm{~mm}$ であ ることから，前後に 1 径ずつ，加減した。足趾把持力 の測定は，十分に練習させた後，休息を設けながら各 条件 2 回ずつ, 合計 6 回, 測定した。また, 課題遂行 の順序による影響を相殺するために，対象者毎に測定 順をランダムに測定した。

統計処理は, 統計ソフトウェア (SPSS Statistics Version 26.0, IBM 社）を使用した。3 条件での足趾把 持力の比較は， 2 回測定の最大值を代表值として反復 測定分散分析および Bonferronni の多重比較検定を採 用した。また，足趾把持力の再現性には，級内相関係 数（1, 1) を求めた。なお，危険率 $5 \%$ 未満を有意差 ありと判断した。

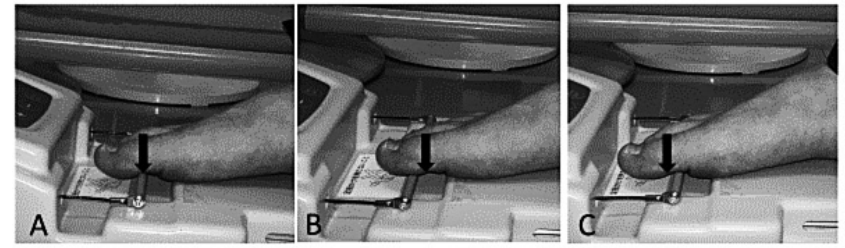

図1足趾把持バーの位置について
$A:$ 第1 1 趾節間関節直上 (IP直上)
B:第1趾節間関節より8mm前方 (IP前方)
C: 第1趾節間関節より $8 \mathrm{~mm}$ 後方 (IP後方)
I: 第1趾節間関節部位 
表 1 各条件における足趾把持力 $(n=24)$

\begin{tabular}{cccc}
\hline & IP 直上 & IP 前方 & IP 後方 \\
\hline 足趾把持力 & $26.6 \pm 6.5^{*}$ & $23.2 \pm 5.0$ & $22.0 \pm 5.3$ \\
\hline
\end{tabular}

(平均值 \pm 標準偏差 $)^{*}: \mathrm{p}<0.05$ IP 前方, IP 後方 $<$ IP 直上 反復測定分散分析, Bonferronni の多重比較検定

表 2 足趾把持力測定值と級内相関係数 $(n=24)$

\begin{tabular}{cccc}
\hline & IP 直上 & IP 前方 & IP 後方 \\
\hline 1 回目 $(\mathrm{kg})$ & $24.8 \pm 6.4$ & $21.9 \pm 4.7$ & $20.6 \pm 5.2$ \\
2 回目 $(\mathrm{kg})$ & $25.8 \pm 6.6$ & $22.3 \pm 5.3$ & $21.4 \pm 5.4$ \\
級内相関係数 & $0.891(0.77-0.95)$ & $0.861(0.71-0.94)$ & $0.887(0.76-0.95)$ \\
$(95 \%$ 信頼区間 $)$ & & & \\
\hline 平均值 標準偏差 & & &
\end{tabular}

\section{結 果}

足趾把持力は, IP 直上が $26.6 \pm 6.5 \mathrm{~kg}$, IP 前方が $23.2 \pm 5.0 \mathrm{~kg}$, IP 後方が $22.0 \pm 5.3 \mathrm{~kg}$ であった。反復 測定分散分析の結果, 3 群間に有意な群間差 $(\mathrm{F}=$ 13. 2, $\mathrm{p}<0.01 ）$ が認められた。さらに, 多重比較検 定の結果, IP 直上の足趾把持力が IP 前方および IP 後方より有意に高値を示した（ $\mathrm{p}<0.05 ） （$ 表 $1 ） 。$

被験者 24 名の級内相関係数 $(1,1)$ は, IP 直上が $\mathrm{r}$ $=0.891$, IP 前方が $\mathrm{r}=0.861$, IP 後方が $\mathrm{r}=0.887 て ゙$ あった（表 2)。

\section{考 察}

本研究では, 足趾把持バーの握り位置について最大 筋力の発揮および再現性の観点から検討した。分析の 結果, 握り位置が IP 直上の足趾把持力は, IP 前方お よび IP 後方より有意に高值を示した。また，級内相 関係数は， 3 条件ともに再現性は高かった。これらの ことから，筋力を最大発揮でき，さらに再現性の観点 から IP 直上での足趾把持力の測定が推奨されること が示された。

本研究で得られた足趾把持力は, 20.0 26. $6 \mathrm{~kg}$ で あった。先行研究における同年代の健常成人男性の足 趾把持力は22.1 26. $8 \mathrm{~kg}$ と報告 ${ }^{16,17)}$ されており, 本研 究の健常成人男性は一般的な筋力レベルの集団であっ たと考えられる。

本結果から, 足趾把持力を最大発揮できる足趾把持 バーの握り位置は，IP 直上であることが示された。 足趾把持力は踵部を支点とし，足趾把持バーを足趾， 前足部の屈曲を等尺性収縮によって手前に引く動作に よって測定される。そのため, 握り位置が IP 直上で あれば，把持バーを IP 関節㮲璧で把持し，手前に引 く力を足趾把持バーに伝えることができる。しかし，
握り位置が IP 前方の場合は, IP 関節㱀譬ではなく末 節骨近位端で把持バーを引くことが要求される。それ により，伝わる力は把持バーを下方に押す力と引く力 に分解され，効率的に足趾把持力を発揮できなかった ものと推察した。また，握り位置が IP 後方の場合は, 基節骨遠位端で把持もしくは IP 関節蚵譬で把持する ために，IP 関節の深屈曲が要求される。IP 関節の参 考可動範囲は $60^{\circ}$ であり ${ }^{18)}$, 握り位置が IP 後方の場合 には足趾把持バーを手前に引く際にはすでにこの参考 可動範囲付近となる。そのため, 引く力を効率的に把 持バーに伝えることができなかったものと考えられた。

本研究により，最大筋力発揮および再現性の観点か ら足趾把持バーの位置は, IP 直上が適切であること が示された。

\section{引用文献}

1) Hirano M, Gomi M, Katoh M:Effect of trunk stability on isometric knee extension muscle strength measurement while sitting. J phys Ther Sci, 2016, 28(9): 2474-2476.

2)村田伸, 忽那龍雄 : 在宅障害高齢者に対する転倒予防対策 一足把持力トレーニング. 日本在宅ケア学会誌, 2004, 7 (2) : 67-74

3) Nagao K, Okuyama R, Taniguti N, et al:: Gender difference in factors affecting the medial longitudinal arch height of the foot in healthy young adults. J Phys Ther Sci, 2018, 30(5): 675 -679 .

4) 角永茂樹, 中井毅, 坂浦博伸・他：CYBEX を用いた全人 工膝関節置換術後の筋力回復の検討. 中部整災誌，2000，43 (6) : 1525-1526

5)高木大輔, 荒井三千雄, 稲庭千弥子 - 他：健常者における 肘の肢位と握力の関係．総合リ八，1997，25(7)：651-654.

6) Teraoka T: Studies on the peculiarity of grip strength in relation to body position and aging. Kobe J Med Sci, 1979, 25(1): $1-17$

7)石崎達郎：地域在宅高齢者の健康寿命を延長するために. 中年からの老化予防に関する医学的研究．東京都老人総合 
研究所, 2000: 94-103.

8) 大塚友吉, 道免和久, 里宇明元 - 他 : 高齢者の握力. リ八 医学, 1994, 31(10): 731-735.

9)相馬正之, 村田伸, 甲斐義浩・他：足関節の角度変化によ る足指把持力の比較. ヘルスプロモーション理学療法研究, 2013, 3 (1) : 21-23.

10)Soma M, Murata S,Kai Y, et al.: An examination of limb position for measuring toe-grip strength. J Phys Ther Sci, 2014, 26(12): 1955-1957.

11) 中江秀幸, 村田伸, 甲斐義浩・他：端座位と立位における 足趾把持力と足関節周囲筋の筋活動の比較. ヘルスプロモー ション理学療法研究, 2013, 3 (1) : 11-14.

12) 大杉紘徳, 本塚貴裕, 佐久間崇・他: 足底への感覚刺激が 足底感覚および足趾把持力に及ぼす影響. ヘルスプロモー ション理学療法研究, 2013, 3 (3) : 129-133.

13)加辺憲人, 黒澤和生, 西田祐介・他：足趾が動的姿勢制御 に果たす役割に関する研究. 理学療法科学, 2002, 17(3)： 199-204.

14) 新井智之, 藤田博暁, 細井俊希・他：地域在住高齢者にお ける足趾把持力と年齢, 性別および運動機能との関連. 理 学療法学, 2011, 38(7) : 489-496.

15)井上椋太, 村田伸, 桐野耕太 - 他 : 地域在住高齢者の転倒 要因に関する研究-身体・認知・精神機能の共分散分析に よる検討 - . ヘルスプロモーション理学療法研究, 2015, 5 (3) : 139-143.

16) 原丈貴：日常生活における疑似的な裸足歩行がバランス機 能および歩行能力に及ぼす影響. デサントスポーツ科学, 2018, $39:$ 234-240.

17) 山田健二, 須藤明治：足把持運動における足部筋活動との 関係. 理学療法科学, 2018, 33(1) : 183-186.

18) 岩倉博光 : 理学療法評価法 (新版). 金原出版株式会社, 東 京, 2001, 34 . 